\title{
ICRAC controls the rapid androgen response in human primary prostate epithelial cells and is altered in prostate cancer
}

\author{
Christian Holzmann ${ }^{1}$, Tatiana Kilch ${ }^{1}$, Sven Kappel ${ }^{1}$, Andrea Armbrüster ${ }^{1}$, Volker \\ Jung ${ }^{2}$, Michael Stöckle ${ }^{2}$, Ivan Bogeski ${ }^{1}$, Eva C. Schwarz ${ }^{1}$ and Christine Peinelt ${ }^{1}$ \\ ${ }^{1}$ Department of Biophysics, Saarland University, Homburg, Germany \\ ${ }^{2}$ Clinics of Urology and Pediatric Urology, Saarland University, Homburg, Germany \\ Correspondence to: Christine Peinelt, email: bpcpei@uks.eu \\ Keywords: Membrane androgen receptor, Orai channel, CRAC channel, prostate cancer, $\mathrm{Ca}^{2+}$ signaling \\ Received: October 9, $2013 \quad$ Accepted: October 27, 2013 Published: October 28, 2013
}

This is an open-access article distributed under the terms of the Creative Commons Attribution License, which permits unrestricted use, distribution, and reproduction in any medium, provided the original author and source are credited.

ABSTRACT:

Labelled 5a-dihydrotestosterone (DHT) binding experiments have shown that expression levels of (yet unidentified) membrane androgen receptors (mAR) are elevated in prostate cancer and correlate with a negative prognosis. However, activation of these receptors which mediate a rapid androgen response can counteract several cancer hallmark functions such as unlimited proliferation, enhanced migration, adhesion and invasion and the inability to induce apoptosis. Here, we investigate the downstream signaling pathways of $\mathrm{MAR}$ and identify rapid DHT induced activation of store-operated $\mathrm{Ca}^{2+}$ entry (SOCE) in primary cultures of human prostate epithelial cells (hPEC) from non-tumorous tissue. Consequently, down-regulation of Orai1, the main molecular component of $\mathrm{Ca}^{2+}$ release-activated $\mathrm{Ca}^{2+}$ (CRAC) channels results in an almost complete loss of DHT induced SOCE. We demonstrate that this DHT induced $\mathrm{Ca}^{2+}$ influx via Orai1 is important for rapid androgen triggered prostate specific antigen (PSA) release. We furthermore identified alterations of the molecular components of CRAC channels in prostate cancer. Three lines of evidence indicate that prostate cancer cells down-regulate expression of the Orai1 homolog Orai3: First, Orai3 mRNA expression levels are significantly reduced in tumorous tissue when compared to nontumorous tissue from prostate cancer patients. Second, mRNA expression levels of Orai3 are decreased in prostate cancer cell lines LNCaP and DU145 when compared to hPEC from healthy tissue. Third, the pharmacological profile of CRAC channels in prostate cancer cell lines and hPEC differ and siRNA based knock-down experiments indicate changed Orai3 levels are underlying the altered pharmacological profile. The cancer-specific composition and pharmacology of CRAC channels identifies CRAC channels as putative targets in prostate cancer therapy.

\section{INTRODUCTION}

In classical steroid receptor pathways, hormones cross the plasma membrane and bind to their cytosolic receptors. Subsequently, these complexes translocate to the nucleus where they trigger gene expression important for many physiological and pathophysiological functions and thus are targets for therapeutic strategies [1-3]. In contrast to the classical pathway where the hormonal effects appear after hours, many cell types display rapid hormone signaling upon steroid hormone stimulation mediated by receptors or ion channels located at the cell surface $[4,5]$.

Even though the molecular identity of mAR is still elusive, their presence has been demonstrated in the membrane of primary prostate tissue and was correlated to the level of differentiation of prostate carcinoma $[6,7]$. $\mathrm{mAR}$ are existent in androgen-sensitive prostate cancer cell line $\mathrm{LNCaP}$ [8] as well as in androgen-insensitive prostate cancer cell lines DU145 and PC3 $[9,10]$. Rapid DHT signaling results in rearrangements of the cytoskeleton, PSA production, inhibition of proliferation, migration, adhesion and invasion and apoptotic regression of prostate cancer cells $[8,11,12]$. Several studies in mice demonstrated the clinical relevance of targeting $\mathrm{mAR}$ in prostate cancer therapy. Macroscopic tumors are reduced upon treatment with testosterone-albumin conjugates, binding exclusively to mAR. In addition, testosterone-BSA triggers tumor cell apoptosis as the fraction of apoptotic 
cells in tumorous tissue is elevated. Co-medication of mice with paclitaxel and testosterone-BSA results in additive tumor inhibitory rates up to $\sim 92 \%[11,12]$. Taken together, targeting mAR pathways in prostate cancer is a highly promising strategy especially as no toxic effects of testosterone-albumin conjugates have been reported in these studies [13].

As a universal mechanism rapid androgen signaling includes an increase in intracellular $\mathrm{Ca}^{2+}$ as second messenger [4]. Previous work proposed that the mAR induced increase in intracellular $\mathrm{Ca}^{2+}$ arises from intracellular $\mathrm{Ca}^{2+}$ store depletion and the $\mathrm{Ca}^{2+}$ influx via voltage gated $\mathrm{Ca}^{2+}$ channels in the plasma membrane in LNCaP cells [14].

During the last few years the molecular components of SOCE and the underlying $\mathrm{Ca}^{2+}$ current $\mathrm{I}_{\mathrm{CRAC}}\left(\mathrm{Ca}^{2+}\right.$ release-activated $\mathrm{Ca}^{2+}$ current) have been identified: stromal interaction molecule STIM1 $[15,16]$ and plasma membrane protein Orail [17-19]. Upon $\mathrm{Ca}^{2+}$ release from intracellular $\mathrm{Ca}^{2+}$ stores, $\mathrm{Ca}^{2+}$ dissociates from an EF hand motif in the luminal section of STIM1. STIM1 molecules cluster and activate $\mathrm{Ca}^{2+}$ influx via Orail ion channels in the plasma membrane [20-24]. A number of studies of the STIM1 homologue STIM2 and the Orai1 homologues Orai2 and Orai3 increasingly reveal disease related roles for these less prominent but ubiquitously expressed isoforms [25].

$\mathrm{I}_{\mathrm{CRAC}}$ mediates a plethora of cellular functions including cell cycle regulation, proliferation and apoptosis [26]. In prostate cancer, $\mathrm{Ca}^{2+}$ signaling via $\mathrm{I}_{\mathrm{CRAC}}$ channels is decreased and subsequently, the low $\mathrm{I}_{\text {CRAC }}$ contributes to cancer hallmark functions in particular uninhibited proliferation and the inability to induce apoptosis [27-29]. In addition, low expression levels of Orail can protect LNCaP cells from several apoptotic pathways [30].

Here, we investigate the role of $\mathrm{I}_{\mathrm{CRAC}}$ channel components in $\mathrm{Ca}^{2+}$ signaling in the rapid response to DHT stimulation. We compare expression levels of STIM1, STIM2, Orai1, Orai2 and Orai3 in tumorous and nontumorous tissue from prostate cancer patients. In addition, we examine the pharmacological profile of $\mathrm{I}_{\mathrm{CRAC}}$ in $\mathrm{hPEC}$ from non-tumorous tissue and prostate cancer cell lines LNCaP and DU145 to investigate $\mathrm{I}_{\text {CRAC }}$ 's molecular key players as potential therapeutic targets.

\section{RESULTS}

\section{DHT induces SOCE in hPEC}

First, we investigate the molecular key players in androgen induced $\mathrm{Ca}^{2+}$ signaling in hPEC. Application of $100 \mathrm{nM}$ DHT in $\mathrm{Ca}^{2+}$ free solution induces a substantial increase in intracellular $\mathrm{Ca}^{2+}$ due to $\mathrm{Ca}^{2+}$ release from intracellular $\mathrm{Ca}^{2+}$ stores as has been described earlier [14].
The subsequent addition of $2 \mathrm{mM} \mathrm{Ca}^{2+}$ induced a rapid increase in intracellular $\mathrm{Ca}^{2+}$ concentration thus confirming that DHT induces SOCE in hPEC. Control cells on which no DHT has been applied release $\mathrm{Ca}^{2+}$ from intracellular $\mathrm{Ca}^{2+}$ stores to some extent, possibly induced by the $\mathrm{Ca}^{2+}$ free solution. But both, $\mathrm{Ca}^{2+}$ release from intracellular $\mathrm{Ca}^{2+}$ stores and SOCE are almost reduced to zero in control cells (Figure 1A). Supplementary Figure 1A shows that store-depletion by sarco-/endoplasmic reticulum $\mathrm{Ca}^{2+}$ ATPase (SERCA) inhibitor thapsigargin (tg) evokes SOCE, confirming the principle mechanism of SOCE in hPEC.

Adenosine-5' -triphosphate (ATP) has been described as signal molecule for prostate epithelial cells [31] as well as melatonin [32]. Application of $100 \mu \mathrm{M}$ ATP activates SOCE but $1 \mu \mathrm{M}$ melatonin does not (Figure 1B) suggesting that ATP induced signaling includes SOCE pathways whereas melatonin signaling pathways do not.

Please note that basal $\mathrm{Ca}^{2+}$ levels vary between 100 nM and $200 \mathrm{nM}$ (Figure 1A and 1B and Supplementary Figure 1A) most likely as data were generated with cell preparations from different patients.

Based on these initial findings we analysed gene expression levels of CRAC channel components Orai1, Orai2, Orai3, STIM1 and STIM2 by qRT-PCR in hPEC from 17 different patients (Figure 1C and Supplementary 1B). Our data suggest that CRAC channels in hPEC are mainly formed by STIM1 and Orai1. Figure 1D represents the ratio of Orai1:Orai3 and STIM1:Orai1 expression pointing towards an STIM1:Orail ratio of $4.6 \pm 0.4$, which, assuming a linear correlation between mRNA and protein levels would be above optimal for maximal SOCE activation [33] and a relatively low Orai1:Orai3 ratio of $4.3 \pm 0.5$ (for comparison, the Orai1: Orai3 ratio is $\sim 70$ in naïve and $\sim 25$ in effector $T_{H}$ cells, [34]). The latter points towards a contribution of approximately one Orai3 subunit to the functional CRAC channel, that has been described as either tetramer [35-40] or hexamer [41] in the past.

The down-regulation of the SOCE component Orail by siRNA significantly reduced the $\mathrm{Ca}^{2+}$ influx rate and peak of SOCE and the $\mathrm{Ca}^{2+}$ plateau is decreased when compared to SOCE in cells transfected with nonsilencing control RNA (Figure 1E, F, G and H). The downregulation of Orai3 had little effect on the $\mathrm{Ca}^{2+}$ influx rate and peak of SOCE, but significantly increased the $\mathrm{Ca}^{2+}$ plateau (Figure 1E, F, G and H). Knock-down efficiencies are shown in Fig. S1c. In order to investigate if downregulation of Orail or Orai3 leads to differences in $\mathrm{Ca}^{2+}$ release from intracellular $\mathrm{Ca}^{2+}$ stores, we subtracted base lines from DHT induced $\mathrm{Ca}^{2+}$ peaks in $0 \mathrm{Ca}^{2+}$ for single cells and analysed the averages. The differences in the degree of store depletion are not significant (Figure 1I).

In conclusion, these data show that rapid DHT response involves $\mathrm{Ca}^{2+}$ signaling via $\mathrm{I}_{\mathrm{CRAC}}$ channels and indicate a key role for Orail whereas the function of Orai3 is less clear. 


\section{Molecular components of ICRAC mediate rapid DHT response}

In order to investigate molecular components of DHT induced SOCE, we used the prostate cancer cell line LNCaP. In a siRNA based assay in $\mathrm{LNCaP}$ cells that were cultured in hormone deprived media for $48 \mathrm{~h}$, downregulation of SOCE components STIM1, STIM2, Orai1, Orai3 or Orai1 and Orai3 led to an overall decrease of DHT induced SOCE when compared to control RNA treated cells (solid lines, Figure 2A). Gene expression levels and efficiency of down-regulation from cells cultured in hormone deprived media for $48 \mathrm{~h}$ are shown in Supplementary Figure 2A and B. Down-regulation of STIM1, Orai1, Orai3 or Orai1 and Orai3 results in a significant decrease of $\mathrm{Ca}^{2+}$ influx rate (Figure 2B), $\mathrm{Ca}^{2+}$ peak (Figure 2C) and $\mathrm{Ca}^{2+}$ plateau (Figure 2D) of SOCE. Down-regulation of STIM2 significantly increased $\mathrm{Ca}^{2+}$ influx rate (Figure 2B), possibly due to a loss of STIM2 suppressing function of STIM1 as described earlier by [42]. Interestingly, STIM2 down-regulation also significantly decreased $\mathrm{Ca}^{2+}$ peak (Figure $2 \mathrm{C}$ ) and $\mathrm{Ca}^{2+}$ plateau (Figure 2D) of SOCE. Global store-depletion by tg results in a higher $\mathrm{Ca}^{2+}$ signal upon $\mathrm{Ca}^{2+}$ release and higher SOCE when compared to DHT induced SOCE (black dotted line (tg) versus black solid line (DHT), Figure 2A). Down-regulation of Orai3 does not decrease but significantly increase $\mathrm{Ca}^{2+}$ influx rate, $\mathrm{Ca}^{2+}$ peak and $\mathrm{Ca}^{2+}$ plateau of tg-induced SOCE (Figure 2A and supplementary Figure 2C).

We next tested for Orail's contribution to rapid androgen induced PSA release. Rapid DHT signaling increased basal PSA production up to $20 \%$ in $\mathrm{LNCaP}$ cells [8]. Comparison of PSA release from $\mathrm{LNCaP}$ cells transfected with control RNA $\left(0.48 \pm 0.08 \mathrm{ng} \cdot \mathrm{mL}^{-1} \cdot 10^{6}\right.$ cells $\left.^{-1}\right)$ or with Orail specific siRNA $(0.39 \pm 0.07$ $\mathrm{ng} \cdot \mathrm{mL}^{-1} \cdot 10^{6}$ cells $\left.^{-1}\right)$ demonstrates that DHT induced PSA release depends on Orail whereas long-term gene expression (after $24 \mathrm{~h}$ ) dependent PSA release appears to be independent on Orail (Figure 2E). In summary, knockdown molecular components of $\mathrm{I}_{\mathrm{CRAC}}$ results in decreased $\mathrm{Ca}^{2+}$ signaling upon DHT stimulation. Down-regulation of main component of CRAC channel component Orai1 reduces DHT induced PSA release.
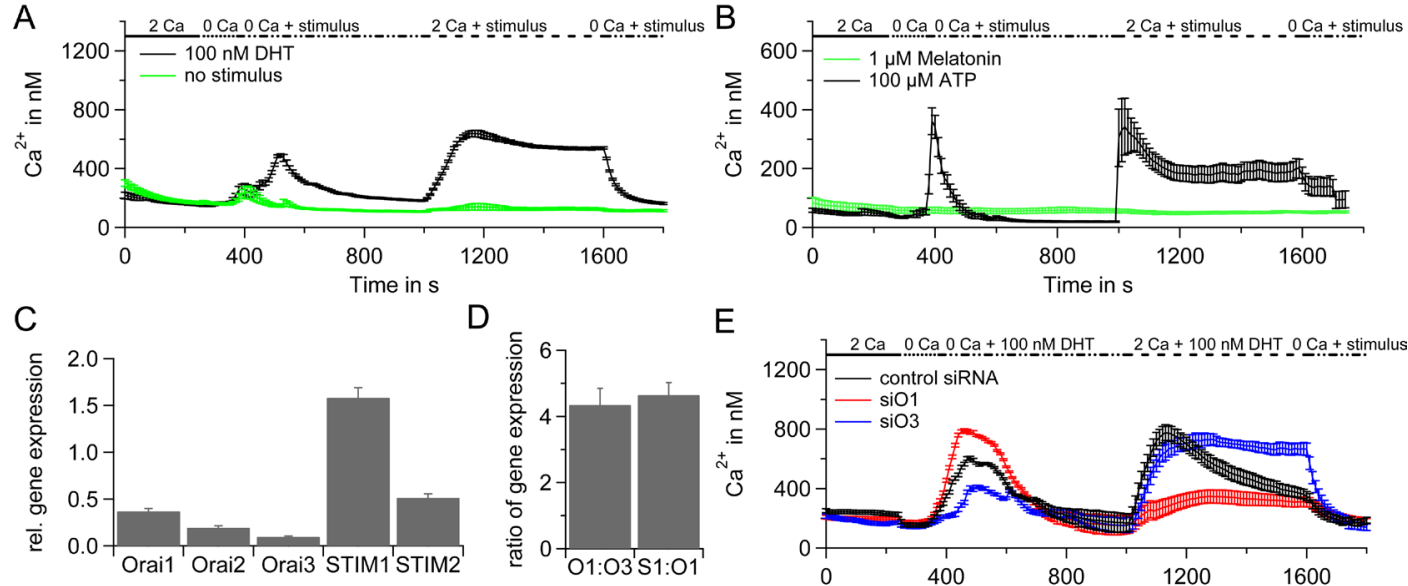

$\mathrm{E}$
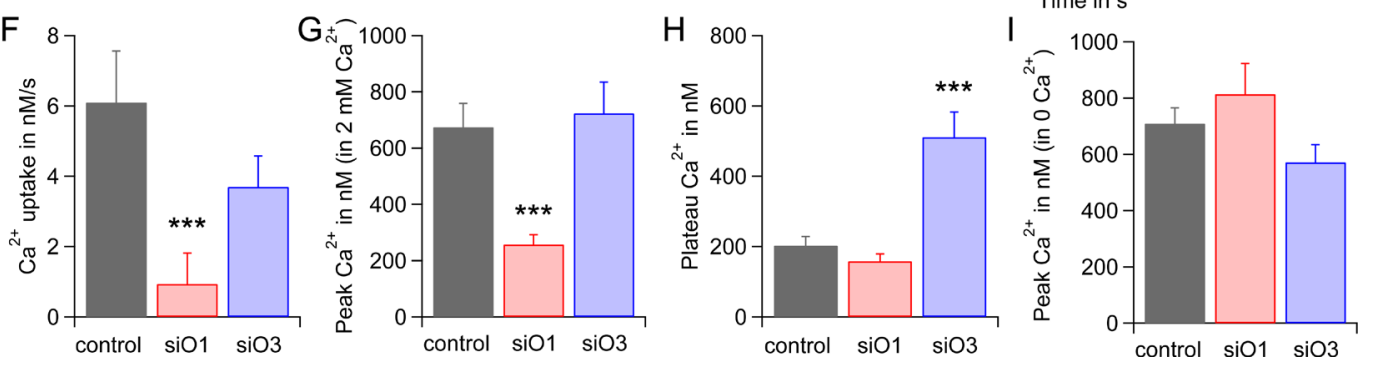

Figure 1: SOCE in hPEC. A) Average intracellular $\mathrm{Ca}^{2+}$ responses $( \pm \mathrm{SEM})$ from a Fura-2 based $\mathrm{Ca}^{2+}$ imaging assay when $100 \mathrm{nM}$ DHT, $(n=44)$ or no stimulus $(n=14)$ were applied are blotted vs. time. Extracellular $\mathrm{Ca}^{2+}$ concentration is indicated in mM. B) Same as A but either $100 \mu \mathrm{M}$ ATP, $\mathrm{n}=37$ (black), or $1 \mu \mathrm{M}$ Melatonin, $\mathrm{n}=14$ (green) were used as stimulus. C) qRT-PCR analyses of Orai1, Orai2, Orai3, STIM1 and STIM2 expression levels from hPEC from 17 different patients normalized to TATA box binding protein (TBP) expression as reference gene. D) Ratio of Orai1:Orai3 and STIM1:Orai1 expression levels. E) DHT induced intracellular Ca ${ }^{2+}$ responses in cells transfected with control RNA (black, $n=38$ ), Orail siRNA (red, $n=33$ ) or Orai3 siRNA (blue, $n=36$ ). F) Average Ca ${ }^{2+}$ influx rates for cells in E when $2 \mathrm{mM} \mathrm{Ca}^{2+}$ and $100 \mathrm{nM}$ DHT were applied. G) Average of $\mathrm{Ca}^{2+}$ peaks for cells in E when $2 \mathrm{mM} \mathrm{Ca}^{2+}$ and $100 \mathrm{nM}$ DHT were applied when baseline for every cell was subtracted. $\mathrm{H}$ ) Average $\mathrm{Ca}^{2+}$ plateaus for cells in E when $2 \mathrm{mM} \mathrm{Ca}^{2+}$ and $100 \mathrm{nM} \mathrm{DHT}$ were

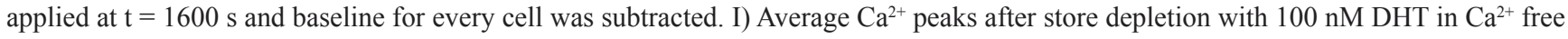
Ringer for cells in $\mathrm{E}$ when baseline for every cell was subtracted. 


\section{ICRAC exhibits a unique 2-APB specific electrophysiological profile in $\mathrm{hPEC}$}

Next, we tested for the properties of $\mathrm{I}_{\text {CRAC }}$ in hPEC in patch clamp experiments in order to investigate typical electrophysiological hallmarks of $\mathrm{I}_{\text {CRAC}}$. We evoked $\mathrm{I}_{\text {CRAC }}$ in a $20 \mathrm{mM} \mathrm{Ca}^{2+}$ Ringer solution by adding $10 \mathrm{mM}$ BAPTA and $50 \mu \mathrm{M}$ inositol-1, 4, 5-trisphosphate ( $\left.\mathrm{IP}_{3}\right)$ to the patch pipette. In these cells $\mathrm{I}_{\mathrm{CRAC}}$ is $\sim 0.5-1 \mathrm{pA} / \mathrm{pF}$ (Figure $3 \mathrm{~A}$, $3 \mathrm{~B}$ and $3 \mathrm{C}$ ). Application of $0 \mathrm{mM} \mathrm{Ca}^{2+}$ abolishes $\mathrm{I}_{\mathrm{CRAC}}$ (Figure 3A, current-voltage curves IVs shown in Figure 3D) and upon application of divalent free solution (DVF) $\mathrm{I}_{\mathrm{CRAC}}$ exhibits large inwardly rectified $\mathrm{Na}^{+}$currents (Figure 3B, IVs shown in Figure 3E). These characteristics are in very good agreement to the literature about native CRAC channels (as discussed below). In many native cells as well as in STIM1/Orail overexpression systems, application of 2-APB $(50 \mu \mathrm{M})$ amplifies and subsequently blocks $\mathrm{I}_{\text {CRAC }}$ $\left(\mathrm{EC}_{50} \sim 3-4 \mu \mathrm{M}, \mathrm{IC}_{50} \sim 8-10 \mu \mathrm{M},[43,44]\right)$. Surprisingly, the 2-APB specific electrophysiological profile of hPEC (Figure 3C and Supplementary Figure 3A, IVs shown in Figure 3F and Supplementary Figure 3D and 2-APB induced dose-responses Figure $3 \mathrm{G}$ and $\mathrm{H}$ ) differs from what is described for native CRAC channels and STIM1/ Orail overexpression systems. The $\mathrm{EC}_{50}$ for potentiation is $\sim 24 \mu \mathrm{M}$ (Figure $3 \mathrm{G}$ ) and the $\mathrm{IC}_{50}$ for inhibition is $82 \mu \mathrm{M}$ (Figure $3 \mathrm{H}$ ). The Orai1:Orai3 ratio in prostate cancer cell lines LNCaP und DU145 is elevated compared to hPEC (Orai1:Orai3 $=17 \pm 0.9, \mathrm{n}=4$, in DU145 and Orai1:Orai3 = $26 \pm 0.9, \mathrm{n}=4$, in $\mathrm{LNCaP}$ calculated from gene expression levels shown in Supplementary Figure 4A). Identical to the experiment in hPEC (Figure 3C and 3F) we determined the 2-APB induced electrophysiological profile in prostate cancer cell lines DU145 (Supplementary Figure 3B and $3 \mathrm{E}$ ) and $\mathrm{LNCaP}$ (Supplementary Figure $3 \mathrm{C}$ and $3 \mathrm{~F}$ ). The statistical analysis in Figure 3I reveals a significant difference in pharmacological profile in DU145 upon application of $75 \mu \mathrm{M} 2$-APB and a significant difference in pharmacological profile in $\mathrm{LNCaP}$ upon application of 50 or $75 \mu \mathrm{M} 2$-APB when compared to hPEC from nontumorous tissue.

As Orai3 is largely expressed in hPEC we next wanted to test if heteromeric Orai1/Orai3 channels might be responsible for the 2-APB specific electrophysiological

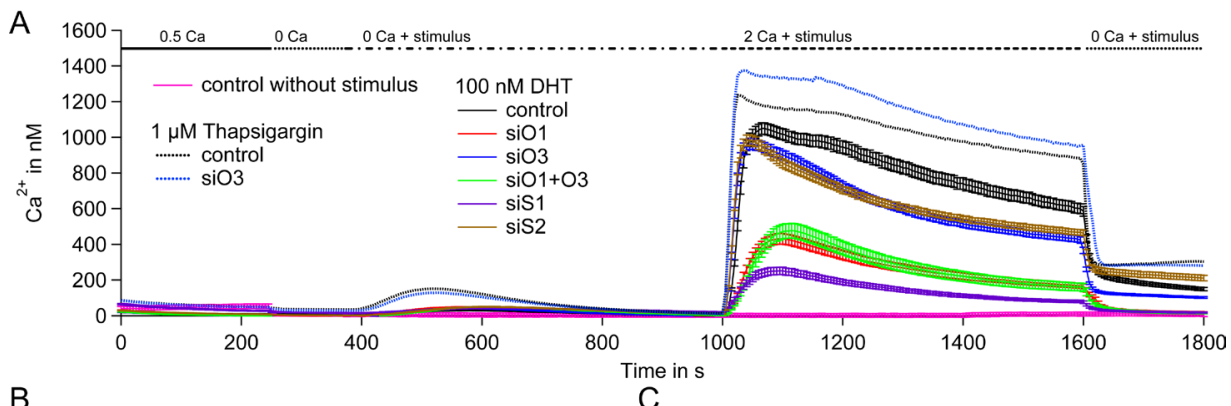

$\mathrm{B}$

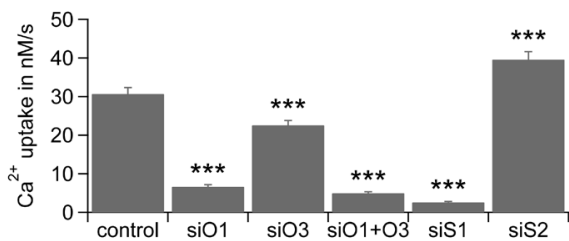

C
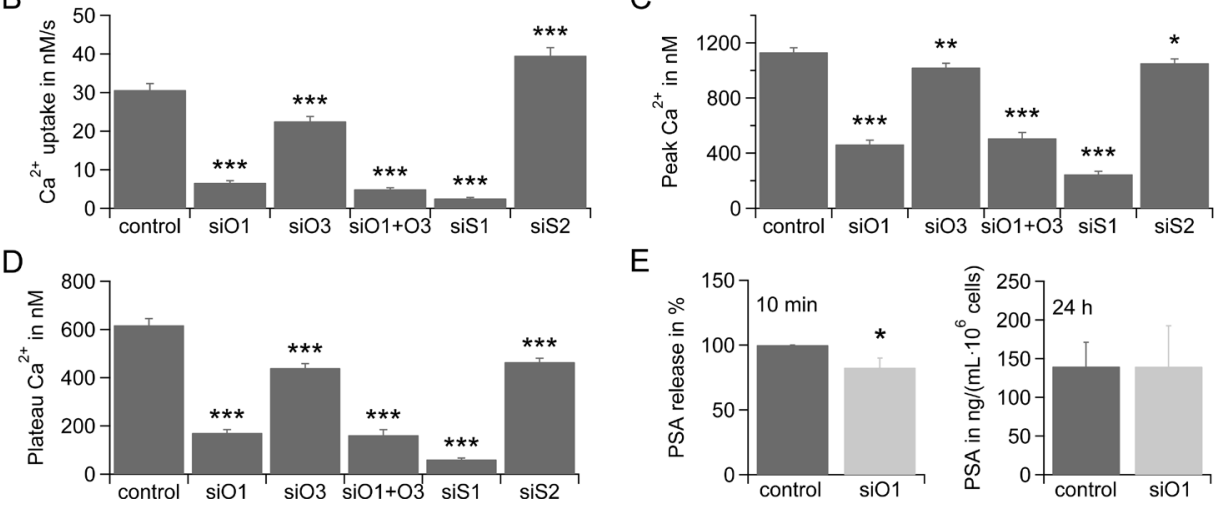

E

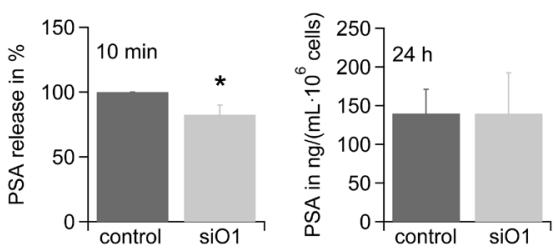

Figure 2: Rapid DHT response in LNCaP depends on SOCE. A) Average intracellular $\mathrm{Ca}^{2+}$ responses $( \pm \mathrm{SEM})$ from a Fura-2 based $\mathrm{Ca}^{2+}$ imaging assay when stores are depleted by application of $100 \mathrm{nM}$ DHT (solid lines) and cells were transfected with control RNA (control, black curve, $n=132$ ), Orai1 siRNA (siO1, red curve, $n=117$ ), Orai3 siRNA (siO3, blue curve, $n=126$ ), Orai1 and Orai3 siRNA ( depleted by application of $1 \mu \mathrm{M}$ tg (dotted line) and cells were transfected with control RNA (control, black curve, $\mathrm{n}=228$ ) or Orai3 siRNA (siO3, blue curve, $n=227$ ) or stores were not depleted (no stimulus) and transfected with control RNA (pink curve, $n=45$ ). Extracellular $\mathrm{Ca}^{2+}$ concentration is indicated in mM. B) Average $\mathrm{Ca}^{2+}$ influx rates from cells in A, when $100 \mathrm{nM}$ DHT and $2 \mathrm{mM} \mathrm{Ca}^{2+}$ were applied. C) Average $\mathrm{Ca}^{2+}$ peaks from cells in A, when $100 \mathrm{nM}$ DHT and $2 \mathrm{mM} \mathrm{Ca}^{2+}$ were applied and baseline for every cell was subtracted. D) Average $\mathrm{Ca}^{2+}$ plateaus from cells in A, when $100 \mathrm{nM}$ DHT and $2 \mathrm{mM} \mathrm{Ca}^{2+}$ were applied and baseline for every cell was subtracted. E) PSA concentration in the media 10 min after stimulation with $100 \mathrm{nM}$ DHT (double determination in $\mathrm{n}=5$ experiments) and PSA concentration in the media $24 \mathrm{~h}$ after stimulation with $100 \mathrm{nM}$ DHT (double determination in $\mathrm{n}=3$ experiments) when cells were transfected with control RNA or Orail siRNA. 
profile.

\section{Orai3 is a regulator of $\mathrm{SOCE}$ and is responsible for the 2-APB specific electrophysiological profile of ICRAC in $\mathrm{LNCaP}$ cells}

Given the extraordinary 2-APB specific electrophysiological profile of hPEC (Figure 3), the low Orai1:Orai3 ratio of $\sim 4$ (Figure 1) and Orai3's property to enhance $\mathrm{Ca}^{2+}$ currents upon 2-APB application [44-48] we tested the ability of Orai3 to shape the 2-APB specific electrophysiological profile of $\mathrm{I}_{\mathrm{CRAC}}$ in the prostate cancer cell line $\mathrm{LNCaP}$ as $\mathrm{LNCaP}$ are less delicate to patch after transfection than hPEC. When 2-APB is applied in a concentration of $30 \mu \mathrm{M}, \mathrm{I}_{\mathrm{CRAC}}$ is enhanced and application of $50 \mu \mathrm{M} 2$-APB results in current enhancement followed by an incomplete current block (Figure 4A, IVs are shown in Supplementary Figure 4C and 4D) as has previously been shown by [49]. In these cells, $\mathrm{I}_{\text {CRAC }}$ exhibits an $\mathrm{EC}_{50}$ of $8 \mu \mathrm{M}$ (Figure $4 \mathrm{~B}$ ) and an $\mathrm{IC}_{50}$ of $36 \mu \mathrm{M}$ (Figure $4 \mathrm{C}$ ). Figure $4 \mathrm{D}$ shows $\mathrm{I}_{\text {CRAC }}$ in a siRNA based assay, when Orai1, Orai3, or both proteins are down-regulated. Analysis of $\mathrm{IP}_{3}$ induced currents show, that down-regulation of Orai3 significantly increases current size, while down-regulation of Orail or Orail and Orai3 significantly decreases the current size (Figure 4D and 4E). Upon siRNA based knock-down residual gene expression on mRNA level range from $11 \pm 5 \%$ to $32 \pm 7 \%$ (Supplementary Figure 4B).

Whereas $\mathrm{I}_{\text {CRAC }}$ in control RNA transfected cells is amplified upon application of $30 \mu \mathrm{M} 2-\mathrm{APB}$, downregulation of Orai1 or Orai1 and Orai3 results in an almost complete loss of 2-APB induced current. The fact that both knock-down conditions give the same result implies that Orail is the stringent requirement for a functional SOCE and that in LNCaP cells the CRAC channel likely exists as a heteromeric Orai1/Orai3 channel. Down-regulation
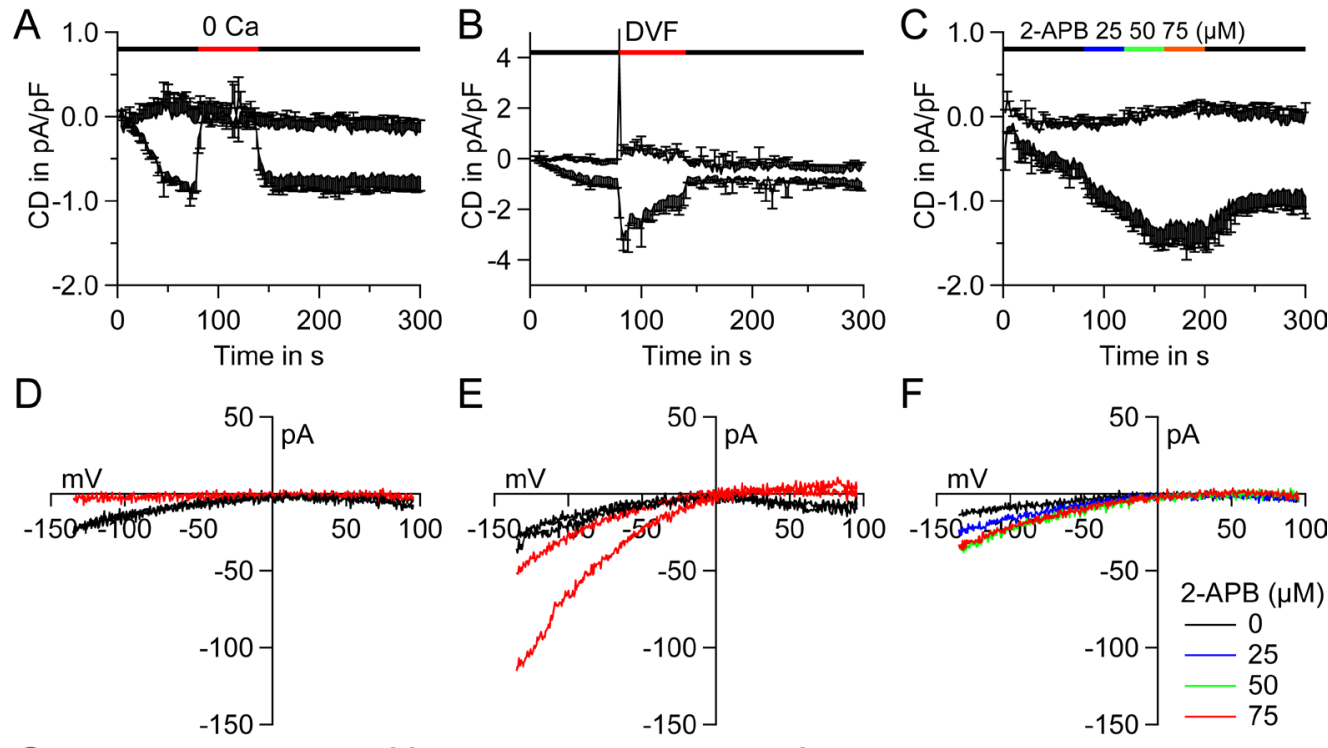

$E$

$\mathrm{F}$
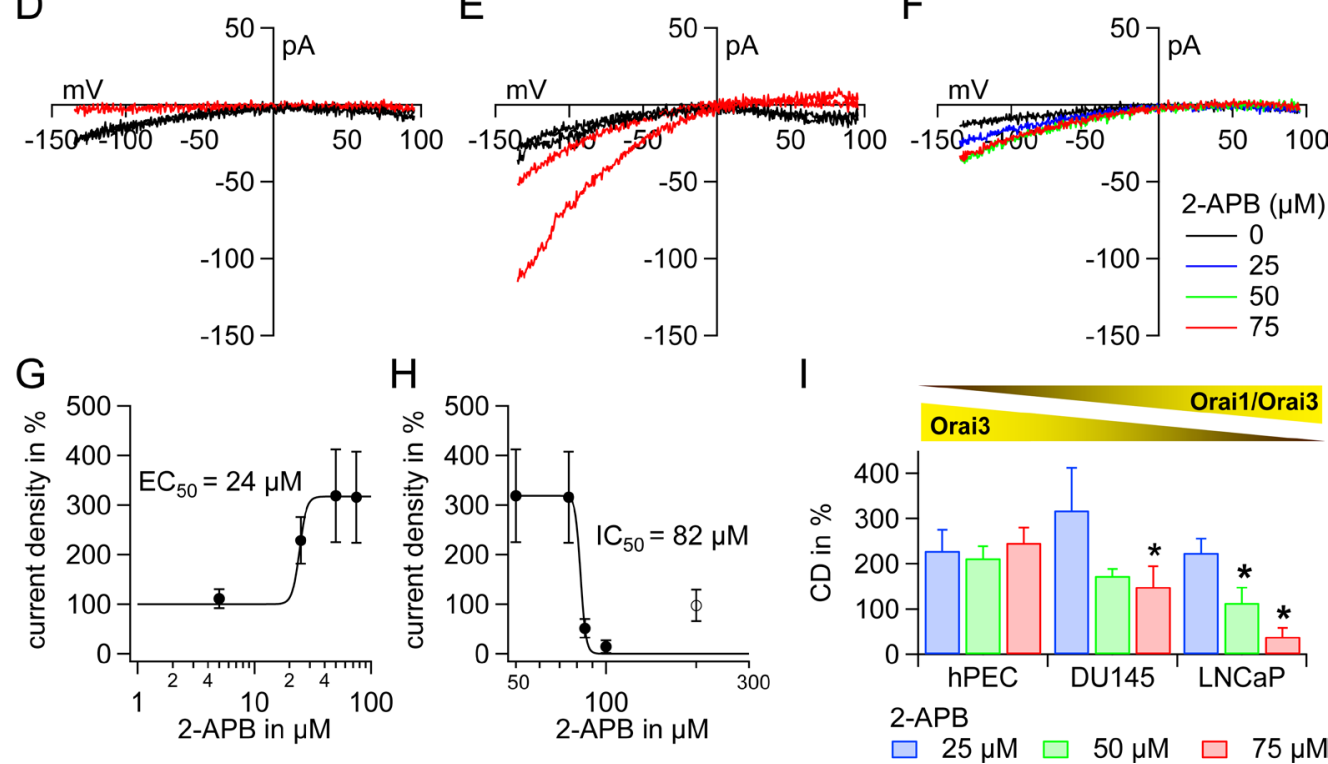

Figure 3: Electrophysiological and pharmacological characterization of ICRAC in hPEC and prostate cancer cell lines. A Time course of $\mathrm{I}_{\text {CRAC }}$ evoked in $\mathrm{hPEC}$ by $50 \mu \mathrm{M} \mathrm{IP}_{3}$ and $10 \mathrm{mM} \mathrm{BAPTA}$ in the patch pipette and $20 \mathrm{mM} \mathrm{Ca}^{2+}$ Ringer in the bath. A $0 \mathrm{mM} \mathrm{Ca}^{2+}$ Ringer $(0 \mathrm{Ca})$ was applied as indicated by the red bar $(\mathrm{n}=4)$. B Same as in A, but a divalent free (DVF) external Ringer was applied as indicated by the red bar $(n=4)$. C Same as in A, but 2-APB was applied as indicated $(n=5)$. D corresponding IVs to A. E corresponding IVs to B. F corresponding IVs to C. G Current densities when 2-APB was applied were normalized to IP ${ }_{3}$ induced current at $\mathrm{t}=80 \mathrm{~s}$ in \%. 2-APB induced current potentiation was analysed with a dose-response fit function and an $\mathrm{EC}_{50}$ of $24 \mu \mathrm{M}$ for potentiation was determined. H Same as G but 2-APB induced current inhibition was analysed. Data were fitted with a dose-response fit function and an $\mathrm{IC}_{50}$ of $82 \mu \mathrm{M}$ for inhibition was determined. I Statistical analysis of 2-APB induced pharmacological profile of hPEC from cells in Figure $3 \mathrm{C}$, DU145 $(\mathrm{n}=6)$ and $\mathrm{LNCaP}(\mathrm{n}=6)$ from experiments performed as in Figure 3C. 
of Orai3 introduces a 2-APB induced block of $\mathrm{I}_{\mathrm{CRAC}}$ that is characteristic for STIM1/Orail mediated currents (Figure 4F). Thus, high expression levels of Orai3 shape a unique pharmacological profile for SOCE and $\mathrm{Ca}^{2+}$ signaling via specific CRAC channels in prostate cancer could be manipulated by substances selective for a specific channel composition.

\section{Relative gene expression of STIM1, STIM2, Orai1, Orai2 and Orai3 in non-tumorous and tumorous tissue from 13 patients with different Gleason score}

We were interested in possible changes of $\mathrm{I}_{\text {CRAC }}$ component expression levels in prostate cancer as $\mathrm{I}_{\mathrm{CRAC}}$ is reduced in prostate cancer resulting in several cancer hallmark functions. We thus determined relative STIM and Orai expression levels in non-tumorous and tumorous tissue from 13 prostate cancer patients by qRT-PCR, from which 13 expressed detectable levels of STIM1, STIM2 and Orai1 and 11 detectable levels of Orai2 and Orai3 (see methods). We find an over-all down-regulation of all $\mathrm{I}_{\text {CRAC }}$ components when gene expression is normalized to TBP (Figure 5A, 5B, 5C, 5D and 5E) or RNAPol (Supplementary Figure 5A, 5B, 5C, 5D and 5E). The different Gleason scores of prostate cancer tumors is indicated by symbols as described in the figure legend. For analysis we pooled data from patients with different Gleason scores. Orai3 is significantly down-regulated when gene expression levels are normalized to TBP
(Figure 5E, $\mathrm{p}=0.03$ and $\mathrm{p}=0.04$ when gene expression levels are normalized to RNAPol, Supplementary Figure 5E). Levels of STIM1:STIM2, STIM1:Orai1, and Orai1:Orai3 gene expression ratios are slightly changed in tumorous tissue (Figure 5F, 5G and 5I and Supplementary Figure 5F, 5G and 5I) whereas the Orai1:Orai2 ratio remains unchanged (Figure $5 \mathrm{H}$ and Supplementary Figure $5 \mathrm{H})$.

Our data suggest a down-regulation of $\mathrm{I}_{\mathrm{CRAC}}$ components in prostate cancer and support the concept of low $\mathrm{Ca}^{2+}$ signaling in prostate cancer cells. Orai3 is significantly down-regulated and the decrease in Orail:Orai3 ratio might reflect a different stoichiometry of Orai1/Orai3 subunits in CRAC channel that open the possibility for specific therapeutic targeting in prostate cancer.

\section{DISCUSSION}

$I_{\text {CRAC }}$ mediates several cellular functions such as cell cycle regulation, proliferation and apoptosis [26]. In prostate cancer, $\mathrm{I}_{\mathrm{CRAC}}$ is well-known to be off-balance [50] and $\mathrm{I}_{\text {CRAC }}$ channels together with a variety of other $\mathrm{Ca}^{2+}$-transporting enzymes are under investigation as therapeutic targets $[51,52]$.

Our results uncover that STIM1 and Orail are $\mathrm{I}_{\text {CRAC }}$ 's major molecular components in hPEC and STIM2, Orai2 and Orai3 are also expressed. $\mathrm{I}_{\mathrm{CRAC}}$ channels are thought to exist either as tetramers [35-40] or as hexamers [41] and the low Orai1:Orai3 ratio of 4.3 supports the
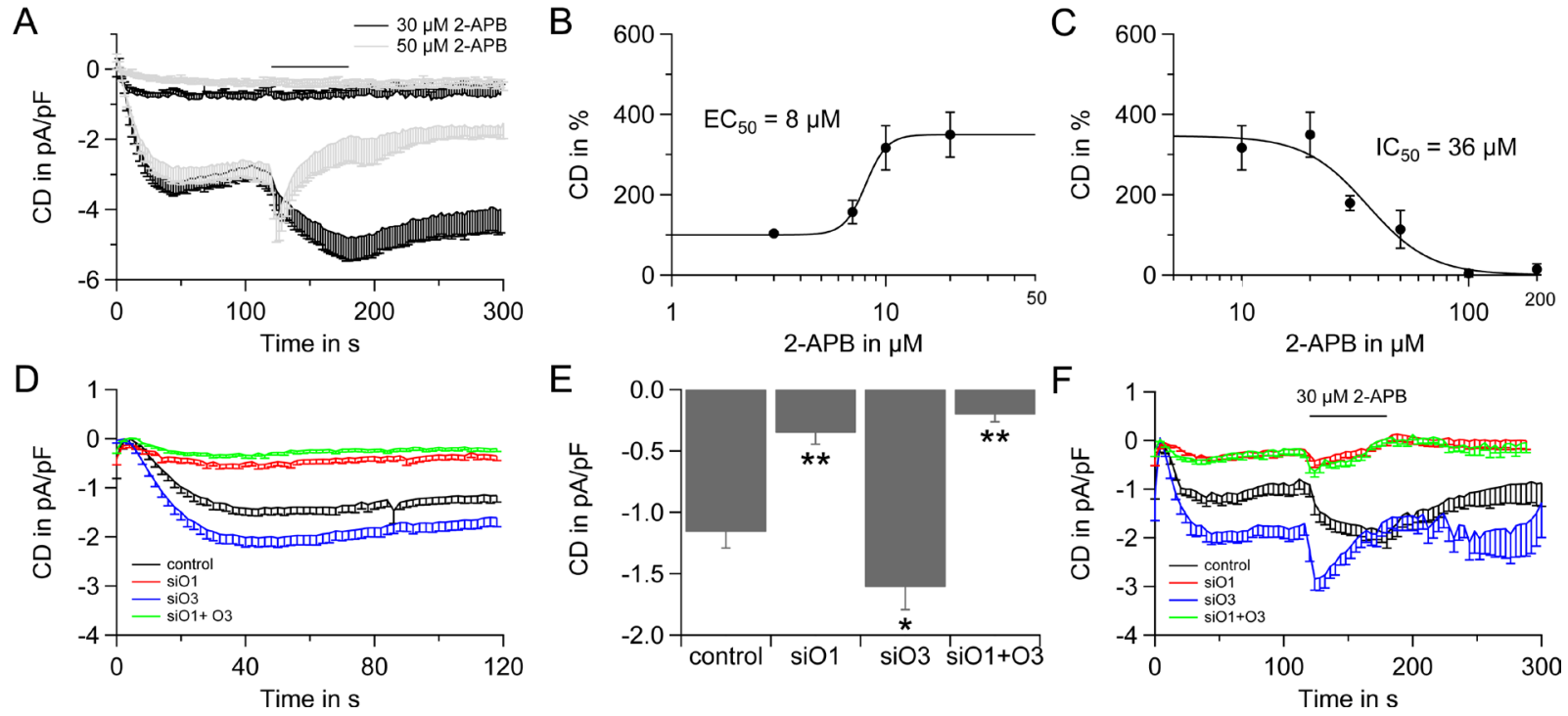

Figure 4: 2-APB specific electrophysiological profile of $\mathbf{L N C a P}$ cells and the role of Orai3. A) Time course of $\mathrm{I}_{\mathrm{CRAC}}$ evoked in LNCaP cells by $50 \mu \mathrm{M} \mathrm{IP}_{3}$ and $10 \mathrm{mM}$ BAPTA in the patch pipette and $20 \mathrm{mM} \mathrm{Ca}^{2+}$ Ringer in the bath. 2-APB was applied as indicated (30 $\mu \mathrm{M}, \mathrm{n}=10$, black line and $50 \mu \mathrm{M}, \mathrm{n}=10$, grey line). B) Dose response for 2-APB induced potentiation, $\mathrm{EC}_{50}=8 \mu \mathrm{M}$. C) Dose response for inhibition of $\mathrm{I}_{\mathrm{CRAC}}$ by 2-APB, $\mathrm{IC}_{50}=36 \mu \mathrm{M}$. D) Time course of $\mathrm{I}_{\mathrm{CRAC}}$ evoked as in A from LNCap cells transfected with non-silencing control RNA (control, black, $\mathrm{n}=21)$, transfected with Orai1 siRNA $(\mathrm{O} 1$, red, $\mathrm{n}=30)$, Orai3 siRNA $(\mathrm{O} 3$, blue, $\mathrm{n}=37)$ or Orai1 and Orai3 siRNA $($ siO1+O3, green, $\mathrm{n}=29)$. Some of the cells in D are also shown in F. E) Current density at $120 \mathrm{~s}$ and statistical analysis for cells from D. F) Time-course of $\mathrm{I}_{\mathrm{CRAC}}$ evoked as described in A when $30 \mu \mathrm{M}$ 2-APB is applied on cells transfected with control RNA (control, black, $\mathrm{n}=$ 11), transfected with Orai1 siRNA (siO1, red, $n=11)$, Orai3 siRNA (siO3, blue, $n=8)$ or Orail and Orai3 siRNA $(\operatorname{siO} 1+\mathrm{O} 3$, green, $\mathrm{n}=9$ ). 
concept of heteromeric Orai1/Orai3 channels in hPEC.

$\mathrm{I}_{\mathrm{CRAC}}$ in hPEC exhibits high $\mathrm{Ca}^{2+}$ selectivity and large monovalent currents in the absence of divalent ions comparable to native CRAC currents from Jurkat $\mathrm{T}$ cells, rat basophilic leukaemia cells (RBL) and mast cells [5355]. The 2-APB specific electrophysiological profile in hPEC is unique with high $\mathrm{EC}_{50}$ and $\mathrm{IC}_{50}$ values $\left(\mathrm{EC}_{50}=\right.$ $24 \mu \mathrm{M}$ and $\mathrm{IC}_{50}=82 \mu \mathrm{M}$ ) when compared to $\mathrm{I}_{\text {CRAC }}$ in a Jurkat T-cell line $\left(\mathrm{EC}_{50}=3 \mu \mathrm{M}\right.$ and $\mathrm{IC}_{50}=10 \mu \mathrm{M}$ [43]) and STIM1 Orail overexpression systems $\left(\mathrm{EC}_{50}=4 \mu \mathrm{M}\right.$ and $\mathrm{IC}_{50}=8 \mu \mathrm{M}$ [44]). Investigation of the 2-APB specific electrophysiological profile in a siRNA based assay in LNCaP cells suggest Orai1/Orai3 heteromeric channels as molecular basis for this unique pharmacology.

We find a significant down-regulation of Orai3 gene expression in tumorous tissue when compared to non-tumerous tissue from prostate cancer patients and an increased Orai1:Orai3 ratio. In addition, a comparison of Orai1:Orai3 gene expression ratios and electrophysiological profiles upon application of 2-APB in prostate cancer cell lines LNCaP, DU145 and hPEC support the idea of low levels of Orai3 in prostate cancer, although Orai3 is not reduced per se in cancer. In breast cancer tissue, Orai3 is up-regulated when compared to healthy tissue and its signaling includes cell cycle progression, apoptosis resistance, the mitogen-activated protein (MAP) kinase pathway and tumor formation [56-59]. The altered composition of CRAC channels in prostate cancer with a shift in Orai1:Orai3 ratio and distinct pharmacological profiles open the possibility to selectively manipulate $\mathrm{I}_{\mathrm{CRAC}}$ activity in cancer cells (e.g. to higher $\mathrm{Ca}^{2+}$ signals and thereby drive cancer cells into apoptosis) without effecting $\mathrm{Ca}^{2+}$ signals in non-cancerous cells.

Targeting $\mathrm{mAR}$ and $\mathrm{mAR}$ induced signaling pathways is an intriguing strategy in the development of therapeutic approaches in prostate cancer [13]. So far, the androgen-induced increase of intracellular $\mathrm{Ca}^{2+}$ has been proposed to be mediated via $\mathrm{Ca}^{2+}$ store-depletion and L-type $\mathrm{Ca}^{2+}$ channels and to involve a pertussis sensitive $\mathrm{G}$ protein-coupled receptor [14, 60]. Evidence has accumulated that mAR activation leads to production of $\mathrm{IP}_{3}$ [61] and mAR induced $\mathrm{IP}_{3}$ production leads to the binding of $\mathrm{IP}_{3}$ to the $\mathrm{IP}_{3}$ receptor and the subsequent release of $\mathrm{Ca}^{2+}$ from intracellular $\mathrm{Ca}^{2+}$ stores $[62,63]$. In 1992, Hoth and Penner demonstrated that $\mathrm{Ca}^{2+}$ store depletion by $\mathrm{IP}_{3}$ triggers $\mathrm{I}_{\mathrm{CRAC}}$ [64]. Here, we demonstrate that rapid DHT signaling induces $\mathrm{Ca}^{2+}$ influx via CRAC channels in hPEC and a knock-down of the pore forming $I_{\text {CRAC }}$ channel subunit Orail results in a dramatic reduction of mAR induced $\mathrm{Ca}^{2+}$ transients in hPEC. In addition, $\mathrm{Ca}^{2+}$ signaling via Orai1 functionally supports PSA release in rapid DHT response.

mAR exhibit higher expression levels in human prostate carcinoma cells when compared to non-tumorous and hyperplastic cells related to the Gleason score of the tumor $[6,7]$. Higher expression levels of mAR are likely to increase store-depletion that is below maximum at DHT concentrations of $100 \mathrm{nM}$ in LNCaP cells (compare storedepletion in Figure 2A, DHT vs tg) due to an elevated IP $_{3}$ production. Patch clamp and imaging experiments indicate down-regulation of Orai3 results in elevated SOCE and $\mathrm{I}_{\text {CRAC }}$ when $\mathrm{Ca}^{2+}$ stores are heavily depleted by either tg or $\mathrm{IP}_{3}$ (Figure 2A, 4D and 4E and Supplementary Figure 2C).

We suggest that high mAR expression levels lead to stronger store depletion and in combination with Orai3 down-regulation to higher $\mathrm{Ca}^{2+}$ signals in prostate cancer. Once induced these elevated $\mathrm{Ca}^{2+}$ signals could bear the potential to counteract cancer hallmark functions that are characterized by low $\mathrm{Ca}^{2+}$ signaling e.g. uninhibited

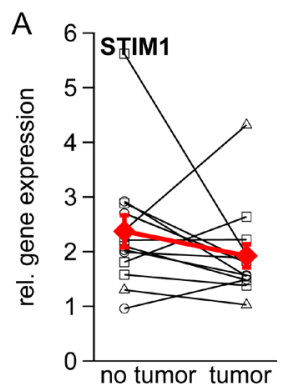

F

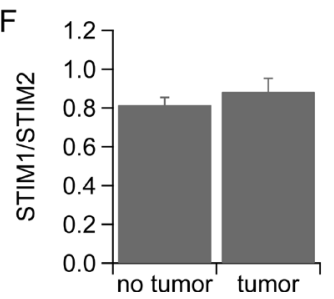

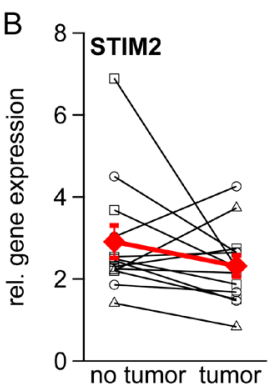

G

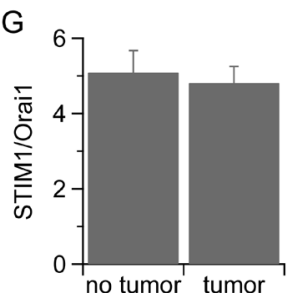

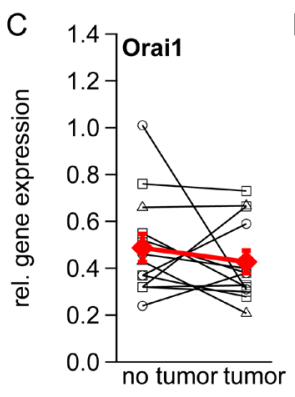

$\mathrm{H}$
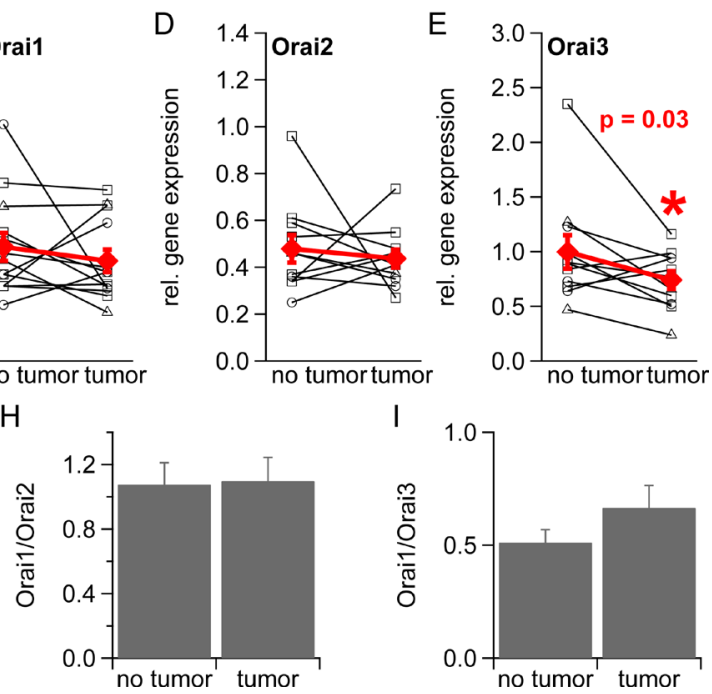

Figure 5: Gene expression of STIM1, STIM2, Orai1, Orai2 and Orai3 in healthy and tumorous human prostate tissue. Relative gene expression of STIM1 $(n=13)$, STIM2 $(n=13)$, Orai1 $(n=13)$, Orai2 $(n=11)$ and Orai3 $(n=11)$ in healthy and tumorous tissue from prostate cancer patients normalized to the reference gene TBP and sorted by Gleason Score $(\mathrm{O}=6, \square=7$ and $\triangle=8)(\mathrm{A}-\mathrm{E}) \mathrm{F}$ ) STIM1:STIM2 ratio. G) STIM1:Orai1 ratio. H) Orai1:Orai2 ratio. I) Orai1:Orai3 ratio. 
proliferation and inability to induce apoptosis. Thus, selective enhancement of $\mathrm{I}_{\text {CRAC }}$ channels in prostate cancer cells can be a promising approach in the development of mAR therapy.

At the moment a novel therapeutic approach against prostate cancer is tested in a clinical trial [65], tg coupled to a chemical cage that is specially cleaved of by prostate specific membrane antigen (PSMA) a prostate specific protease [66]. This so-called smart bomb is active only in prostate cancer cells. $\mathrm{I}_{\mathrm{CRAC}}$ channels might be pharmacologic targets for the treatment of prostate cancer if they can be selectively manipulated without affecting $I_{\text {CRAC }}$ channels in healthy cells. Thus, future therapies could include smart bombs on prostate cancer-specific $\mathrm{I}_{\text {CRAC }}$ channels.

\section{MATERIAL \& METHODS}

\section{Cell culture and prostate tissue collection}

Prostate cancer lines Lymph Node Carcinoma of the Prostate (LNCaP) and DU145 were purchased from American Type Cell Culture Collection (ATCC, Rockville, MD, USA) and cultured with RPMI Medium 1640 (Life Technologies) supplemented with $10 \%$ FCS and $1 \%$ Pen/ Strep (Life Technologies).

Prostate tissue was obtained from prostectomy specimens (Ethics approval 168/05, Ärztekammer des Saarlandes).

Human prostate epithelial cells (hPEC) were isolated with slight modifications according to [67]. Pieces from healthy tissues are washed in phosphate buffer solution and cut into cubes with a side length of $1 \mathrm{~mm}$ and placed into cell culture flasks. These small tissue cubes are wetted with PrEBM (Prostate Cell Basal Medium, \#CC3165, Lonza) supplemented with PrEGM Single Quots Supplements (\#CC-4177, Lonza). Under these conditions prostate epithelial cells start to form a layer around the tissue piece after 2 to 6 days. After an adequate cell layer has been formed, pieces are removed and cells are taken in culture. For passaging Cell Dissociation Solution (\#C5789, Sigma) was used to detach cells and cells were not grown in media described above.

For comparison of expression levels of target genes via qRT-PCR in healthy and cancer prostate tissues primary prostate adenocarcinoma samples, which were obtained after radical prostatectomy from thus far untreated prostate cancer patients, were investigated. Following prostatectomy, the specimens were dissected by a pathologist, snap frozen, and stored at $-80^{\circ} \mathrm{C}$. Only samples containing $>50 \%$ tumor cells were included in the study. In the present subset of 13 prostate cancer samples were classified with Gleason score as indicated.

\section{Quantitative RealTime-PCR (qRT-PCR)}

Total RNA from LNCaP, DU145 and hPEC was isolated with TRIzol Reagent (Life Technologies) and from prostate cancer tissue with RNeasy Mini kit (Qiagen). For reverse transcription $0.8 \mu \mathrm{g}$ of isolated total RNA was used.

$0.5 \mu \mathrm{l}$ complementary DNA (cDNA) and 300 $\mathrm{nM}$ primer were used in a QuantiTect SYBRgreen kit (Qiagen). PCR conditions were as follows: $15 \mathrm{~min}$ at $95^{\circ} \mathrm{C} ; 45$ cycles, $30 \mathrm{~s}$ at $95^{\circ} \mathrm{C} ; 45 \mathrm{~s}$ at $58^{\circ} \mathrm{C}$; and $30 \mathrm{~s}$ at $72^{\circ} \mathrm{C}$ and finally a cycle $\left(60 \mathrm{~s}, 95^{\circ} \mathrm{C} ; 30 \mathrm{~s} 55^{\circ} \mathrm{C} ; 30 \mathrm{~s} 95^{\circ} \mathrm{C}\right)$ to determine specificity by a dissociation curve using the MX3000 cycler (Stratagene). Expression of target genes were normalized to the expression of the reference genes RNA polymerase II (RNAPol, NM_000937) and/or TATA box binding protein (TBP, NM_003194). Primer sequences were as follows for Orai 1 5'atgagcctcaacgagcact3' (forward) and 5'gtgggtagtcgtggtcag3' (reverse), for Orai3 were 5'gtaccgggagttcgtgca3' (forward) and 5'ggtactcgtggtcactct3' (reverse), for STIM1 were $5^{\prime}$ cagagtctgcatgaccttca 3 ' (forward) and $5^{\prime}$ gcttcetgcttagcaaggtt 3' (reverse), for STIM2 were 5' gtctccattccaccctatcc 3' (forward) and 5' ggctaatgatccaggaggtt $3^{\prime}$ (reverse), TBP were 5' cggagagttctgggattgt 3 ' (forward) and 5' ggttcgtggctctcttatc 3' (reverse) and RNAPol were 5' ggagattgagtccaagttca 3' (forward) and 5' gcagacacaccagcatagt 3' (reverse).

\section{Ca2+ Imaging}

Bath solution contained (in $\mathrm{mM}$ ): $155 \mathrm{NaCl}, 4.5$ $\mathrm{KCl}, 2 \mathrm{MgCl}_{2}, 10$ glucose, 5 HEPES (pH 7.4 with $\mathrm{NaOH}$ ), and $\mathrm{CaCl}_{2}$ was adjusted as indicated. Stock solutions of tg were prepared in DMSO at a concentration of $1 \mathrm{mM}$ and of DHT in ethanol at a concentration of $5 \mathrm{mM}$. For $\mathrm{Ca}^{2+}$ imaging assays (see below) LNCaP cells and hPEC were cultured for $48 \mathrm{~h}$ in hormone deprived RPMI media (Sigma R7509), supplemented with 10\% charcoal stripped FBS (Sigma F6765) and 2 mM L-glutamine, when DHT was used as a stimulus.

Cells were plated on glass cover slips for at least 24 $\mathrm{h}$ and loaded with $1 \mu \mathrm{M}$ Fura-2/AM at $37^{\circ} \mathrm{C}$ for $20 \mathrm{~min}$. Afterwards glass coverslips were placed in a perfusion chamber in a Zeiss Axio Observer.A1 fluorescence microscope equipped with a "Plan-Neofluar" 20x/0.4 objective (Zeiss). The excitation light generated by a Polychrome V in a TILL Photonics realtime imaging system alternated at 340 and $380 \mathrm{~nm}$ and the exposure time was set to $50 \mathrm{~ms}$ in each channel. Light intensity at emission wavelength $440 \mathrm{~nm}$ was detected every $5 \mathrm{~s}$ and digitized by a charge-coupled device camera (Q-Imaging Retiga 2000RV). Data was analysed with TILL Vision software. Intracellular $\mathrm{Ca}^{2+}$ concentration was calculated from the equation $\left[\mathrm{Ca}^{2+}\right]_{\mathrm{i}}=\mathrm{K}\left(\mathrm{R}-\mathrm{R}_{\min }\right) /\left(\mathrm{R}_{\max }-\mathrm{R}\right)$ in which 
$\mathrm{K}, \mathrm{R}, \mathrm{R}_{\text {min }}$ and $\mathrm{R}_{\max }$ where determined in the corresponding in situ calibration for hPEC and LNCaP cells according to [68].

\section{Electrophysiology}

Tight seal whole-cell patch clamp experiments were performed with a Patchmaster software controlled EPC-10 patch-clamp amplifier (HEKA). The fire-polished patchpipettes had resistances between 2 and $4 \Omega \mathrm{M}$. Voltage ramps of $50 \mathrm{~ms}$ duration were delivered every $2 \mathrm{~s}$ from a holding potential of $0 \mathrm{mV}$ spanning $-150 \mathrm{mV}$ to $+100 \mathrm{mV}$ for hPEC and $-150 \mathrm{mV}$ to $+150 \mathrm{mV}$ for the LNCaP cells. Capacitive currents were determined and corrected before each voltage ramp. Current sample rate was $3 \mathrm{kHz}$ and data were filtered at $1 \mathrm{kHz}$. All voltages were corrected for a liquid junction potential of $-10 \mathrm{mV}$. For analysis leak currents before current activation were subtracted and currents extracted at $-130 \mathrm{mV}$ and $80 \mathrm{mV}$ and blotted vs time.

The bath solutions contained in mM: $95 \mathrm{NaCl}, 2.8$ $\mathrm{KCl}, 20 \mathrm{CaCl}_{2}, 2 \mathrm{MgCl}_{2}, 10$ HEPES, $10 \mathrm{TEACl}, 10 \mathrm{CsCl}$, 10 glucose for LNCaP cells and $120 \mathrm{NaCl}, 10 \mathrm{TEACl}, 20$ $\mathrm{CaCl}_{2}, 2 \mathrm{MgCl}_{2}, 10 \mathrm{HEPES}, 10$ glucose for hPEC. The $\mathrm{pH}$ was adjusted with $\mathrm{NaOH}$ to 7.2 and osmolarity was $300 \mathrm{mosmol} / \mathrm{L}$ for cell lines and 330 for primary prostate epithelial cells. In $0 \mathrm{mM} \mathrm{Ca}{ }^{2+}$ solution $\mathrm{CaCl}_{2}$ was omitted and in divalent free solution (DVF) $\mathrm{MgCl}_{2}$ and $\mathrm{CaCl}_{2}$ were replaced by $10 \mathrm{mM}$ EDTA, osmolarity was adjusted to 330 mosmol/L with glucose. In 2-APB experiments 2-APB was added as indicated. Pipette solution contained in $\mathrm{mM}$ : $120 \mathrm{Cs}$ glutamate, 10 BAPTA, $10 \mathrm{HEPES}, 3 \mathrm{MgCl}_{2}$ and $0.05 \mathrm{IP}_{3}$ for LNCaP cells and $140 \mathrm{Cs}$ glutamate, $8 \mathrm{NaCl}$, 10 BAPTA, 10 HEPES, $3 \mathrm{MgCl}_{2}$ and $0.05 \mathrm{IP}_{3}$ for hPEC. For reasons of comparability DU145 and LNCaP in Fig. 3 and S3 were patched under the same conditions as hPEC.

\section{Data analysis and statistics}

Data were analyzed with TILLVision (TILL Photonics), Fitmaster 2.35 (HEKA), Igor Pro (Wavemetrics), and Microsoft Excel (Microsoft). Data are given as means \pm SEM. Asterisks indicate significance determined by an unpaired, two-sided Student's t-test *p $<0.05, * * \mathrm{p}<0.01, * * * \mathrm{p}<0.001$. Significance of changes in PSA release assays was tested with a one-sided unpaired t-test. Significance of changes of relative gene expression in tissue probes from patients was analyzed with a paired t-test. $\mathrm{EC}_{50}$ and $\mathrm{IC}_{50}$ values were determined by a fit with Hill's equations (least-squares method). For qRT-PCR relative expression was calculated according to the $\Delta \mathrm{Cq}$ method $\left(2^{-\Delta \mathrm{Cq}}\right)$ where $\mathrm{Cq}$ values are determined with the MX3000 software and excluded from analysis when they exceeded 35 cycles.

\section{Small interfering RNA transfection (siRNA)}

SiRNA tranfections were perfomed with $0.12 \mathrm{nmol}$ of siRNA with a Nucleofector II (Lonza) nucleofector using Nucleofector transfection Kit R (Lonza) according to manufacturer' instructions. All siRNAs were from Qiagen or Microsynth and were in part modified according to [69]. Orail siRNAs were Hs_TMEM142A_1, \#SI03196207 [sense: 5'OMeC-OMeG-GCCUGAUCUUUAUCGd(UCU)OMeU-OMeT-OMeT3'; antisense: 3'OMeGOMeC-CGGACUAGAAAUAGCAGAd(A) 5']

and Hs_TMEM142A_2, \#SI04215316 [sense: 5'OMeC-OMeA-ACAUCGAGGCGGUGA)d(GCA) OMeA-OMeT-OMeT3'; antisense: 3'OMeG-OMeTUGUAGCUCCGCCACUCGUd(U)5']. Orai3 siRNAs were Hs_TMEM142C_2, \# SI04174191 [sense: 5'OMeC-OMeA-CCAGÜGGCUACCUCCd(CUU)

OMeA-OMeTOMeT3'; antisense: 3'OMeGOMeT-GGUCACCGAUGGAGGGAAd(U)5']

and Hs_TMEM142C_5, \#SI04348876 [sense: 5'OMeT-OMeC-CUUAGCCCUUGAAAU)d(ACA)

OMeA-OMeT-OMeT3'; antisense: 3'OMeA-OMeG-GAAUCGGGAACUUUAUGUd(U)5']. STIM1 siRNAs were Hs_STIM1_5, \# SI03235442 [sense: 5'OMeUOMeGAGGGUGGĀGGUGCAAUd(AUU)dOMeA-

dOMeT-dOMeT3'; antisense: 3'OMeA-OMeC-UCCACCUCCACGUUAUAAd(U)5'] and Hs_STIM1_6, \# SI04165175 [sense: 5'OMeC-OMeU-GGUGGUGUCUAUCGUd(UAU) OMeU-OMeT-OMeT3'; antisense: 3'OMeG-OMeA-CCACCACAGAUAGCAAUAd(A)5']. STIM2 siRNAs were Stim2_6 (Microsynth), [sense: 5'UAAGCAGCAUCCCĀCAUGAdTdT3'; antisense: 3'dTdTAUUCGUCGUAGGGUGUACU5'] and Stim2 7 (Microsynth), [sense: 5'AAUUUAGAGCGCAAAAUGAdTdT3'; antisense: 3'dTdTUUAAAUCUCGCGUUUUACU5'] and Stim2_8 (Microsynth) [sense: 5'GUGCACGAACCUUCAUUUAdTdT3'; antisense: 3'dTdTCACGUGCUUGGAAGUAAAU5']. Non-silencing RNA were MS_control_mod [sense: 5'OmeA-OMeA-AGGUAGUGUĀAUCGC̄'d(CUU) OMeG-OmeT-OMeT3'; antisense: 3'OmeT-OmeTUCCAUCACAUUAGCGGAAdC 5'].

\section{Determination of prostate specific antigen (PSA)}

LNCaP cells were transfected with either control or Orail specific siRNA and seeded in 6-well plates. After $24 \mathrm{~h}$ medium was replaced by hormone deprived medium for $48 \mathrm{~h}$. After $100 \mathrm{nM}$ DHT has been added, $250 \mu \mathrm{l}$ of supernatant was removed at the time points indicated and total PSA within the supernatant was determined in an ECLIA (ElectroChemiLuminescence ImmunoAssay) using a cobas system (Roche). PSA was determined in ng/ $\mathrm{mL}$ and normalized to $10^{6}$ cells. 


\section{ACKNOWLEDGEMENT}

We acknowledge funding of several DFG projects (SFB 1027 (C4) and BO 3643/2-1 to IB, SFB 894 (A2) and PE1478/5-1 to CP). IB acknowledges funding by the AvH Foundation via the joint German-Macedonian project (DEU/1128670) and the HOMFORexcellent program of the Saarland University. VJ acknowledges funding by the Stiftung Europrofession and VJ and ES by HOMFOR of the Saarland University. We thank Helga Angeli, Petra Frieß, Gertrud Schwär and Cora Stephan for their technical support. We thank Markus Hoth for constant support and Barbara A. Niemeyer and Markus Hoth for scientific discussion and careful reading of the manuscript.

\section{REFERENCES}

1. Evans RM. The steroid and thyroid hormone receptor superfamily. Science. 1988; 4854: 889-895

2. Huang P, Chandra V and Rastinejad F. Structural overview of the nuclear receptor superfamily: insights into physiology and therapeutics. Annu.Rev.Physiol. 2010; 247-272

3. Cleve A, Fritzemeier KH, Haendler B, Heinrich N, Moller C, Schwede W and Wintermantel T. Pharmacology and clinical use of sex steroid hormone receptor modulators. Handb.Exp.Pharmacol. 2012; 214: 543-587

4. Michels G and Hoppe UC. Rapid actions of androgens. Front.Neuroendocrinol. 2008; 2: 182-198

5. Wagner TF, Loch S, Lambert S, Straub I, Mannebach S, Mathar I, Dufer M, Lis A, Flockerzi V, Philipp SE and Oberwinkler J. Transient receptor potential M3 channels are ionotropic steroid receptors in pancreatic beta cells. Nat. Cell Biol. 2008; 12: 1421-1430

6. Dambaki C, Kogia C, Kampa M, Darivianaki K, Nomikos M, Anezinis P, Theodoropoulos PA, Castanas E and Stathopoulos EN. Membrane testosterone binding sites in prostate carcinoma as a potential new marker and therapeutic target: study in paraffin tissue sections. BMC Cancer. 2005; 148

7. Stathopoulos EN, Dambaki C, Kampa M, Theodoropoulos PA, Anezinis P, Delakas D, Delides GS and Castanas E. Membrane androgen binding sites are preferentially expressed in human prostate carcinoma cells. BMC Clin. Pathol. 2003; 1

8. Kampa M, Papakonstanti EA, Hatzoglou A, Stathopoulos $\mathrm{EN}$, Stournaras $\mathrm{C}$ and Castanas E. The human prostate cancer cell line LNCaP bears functional membrane testosterone receptors that increase PSA secretion and modify actin cytoskeleton. FASEB J. 2002; 11: 1429-1431

9. Papadopoulou N, Charalampopoulos I, Anagnostopoulou V, Konstantinidis G, Foller M, Gravanis A, Alevizopoulos $\mathrm{K}$, Lang $\mathrm{F}$ and Stournaras C. Membrane androgen receptor activation triggers down-regulation of PI-3K/Akt/NFkappaB activity and induces apoptotic responses via $\mathrm{Bad}$, FasL and caspase-3 in DU145 prostate cancer cells. Mol.
Cancer. 2008; 88-4598-7-88

10. Lyng FM, Jones GR and Rommerts FF. Rapid androgen actions on calcium signaling in rat sertoli cells and two human prostatic cell lines: similar biphasic responses between 1 picomolar and 100 nanomolar concentrations. Biol.Reprod. 2000; 3: 736-747

11. Kampa M, Kogia C, Theodoropoulos PA, Anezinis P, Charalampopoulos I, Papakonstanti EA, Stathopoulos EN, Hatzoglou A, Stournaras C, Gravanis A and Castanas E. Activation of membrane androgen receptors potentiates the antiproliferative effects of paclitaxel on human prostate cancer cells. Mol.Cancer.Ther. 2006; 5: 1342-1351

12. Hatzoglou A, Kampa M, Kogia C, Charalampopoulos I, Theodoropoulos PA, Anezinis P, Dambaki C, Papakonstanti EA, Stathopoulos EN, Stournaras C, Gravanis A and Castanas E. Membrane androgen receptor activation induces apoptotic regression of human prostate cancer cells in vitro and in vivo. J.Clin.Endocrinol.Metab. 2005; 2: 893903

13. Lang F, Alevizopoulos $\mathrm{K}$ and Stournaras C. Targeting membrane androgen receptors in tumors. Expert Opin.Ther. Targets. 2013; 8: 951-963

14. Steinsapir J, Socci R and Reinach P. Effects of androgen on intracellular calcium of LNCaP cells. Biochem.Biophys. Res.Commun. 1991; 1: 90-96

15. Roos J, DiGregorio PJ, Yeromin AV, Ohlsen K, Lioudyno M, Zhang S, Safrina O, Kozak JA, Wagner SL, Cahalan MD, Velicelebi G and Stauderman KA. STIM1, an essential and conserved component of store-operated $\mathrm{Ca} 2+$ channel function. J.Cell Biol. 2005; 3: 435-445

16. Liou J, Kim ML, Heo WD, Jones JT, Myers JW, Ferrell JE,Jr and Meyer T. STIM is a Ca2+ sensor essential for $\mathrm{Ca} 2+$-store-depletion-triggered $\mathrm{Ca} 2+$ influx. Curr.Biol. 2005; 13: 1235-1241

17. Vig M, Peinelt C, Beck A, Koomoa DL, Rabah D, KoblanHuberson M, Kraft S, Turner H, Fleig A, Penner R and Kinet JP. CRACM1 is a plasma membrane protein essential for store-operated Ca2+ entry. Science. 2006; 5777: 12201223

18. Zhang SL, Yeromin AV, Zhang XH, Yu Y, Safrina O, Penna A, Roos J, Stauderman KA and Cahalan MD. Genome-wide RNAi screen of $\mathrm{Ca}(2+)$ influx identifies genes that regulate $\mathrm{Ca}(2+)$ release-activated $\mathrm{Ca}(2+)$ channel activity. Proc.Natl.Acad.Sci.U.S.A. 2006; 24: 9357-9362

19. Feske S, Gwack Y, Prakriya M, Srikanth S, Puppel SH, Tanasa B, Hogan PG, Lewis RS, Daly M and Rao A. A mutation in Orail causes immune deficiency by abrogating CRAC channel function. Nature. 2006; 7090: 179-185

20. Lewis RS. Store-operated calcium channels: new perspectives on mechanism and function. Cold Spring Harb Perspect.Biol. 2011; 12: 10.1101/cshperspect.a003970

21. Wu MM, Buchanan J, Luik RM and Lewis RS. Ca2+ store depletion causes STIM1 to accumulate in ER regions closely associated with the plasma membrane. J.Cell Biol. 
2006; 6: 803-813

22. Stathopulos PB, Li GY, Plevin MJ, Ames JB and Ikura M. Stored $\mathrm{Ca} 2+$ depletion-induced oligomerization of stromal interaction molecule 1 (STIM1) via the EF-SAM region: An initiation mechanism for capacitive Ca2+ entry. J.Biol. Chem. 2006; 47: 35855-35862

23. Xu P, Lu J, Li Z, Yu X, Chen L and Xu T. Aggregation of STIM1 underneath the plasma membrane induces clustering of Orai1. Biochem.Biophys.Res.Commun. 2006; 4: 969976

24. Smyth JT, DeHaven WI, Bird GS and Putney JW,Jr. Role of the microtubule cytoskeleton in the function of the storeoperated Ca2+ channel activator STIM1. J.Cell.Sci. 2007; Pt 21: 3762-3771

25. Hoth M and Niemeyer BA. The Neglected CRAC Proteins: Orai2, Orai3, and STIM2. Curr.Top.Membr. 2013; 237-271

26. Putney JW. The physiological function of store-operated calcium entry. Neurochem.Res. 2011; 7: 1157-1165

27. Vanden Abeele F, Skryma R, Shuba Y, Van Coppenolle F, Slomianny C, Roudbaraki M, Mauroy B, Wuytack F and Prevarskaya N. Bcl-2-dependent modulation of $\mathrm{Ca}(2+)$ homeostasis and store-operated channels in prostate cancer cells. Cancer.Cell. 2002; 2: 169-179

28. Shapovalov G, Skryma R and Prevarskaya N. Calcium Channels and Prostate Cancer. Recent.Pat.Anticancer Drug Discov. 2012;

29. Prevarskaya N, Skryma R and Shuba Y. Ion channels and the hallmarks of cancer. Trends Mol.Med. 2010; 3: 107-121

30. Flourakis M, Lehen'kyi V, Beck B, Raphael M, Vandenberghe M, Abeele FV, Roudbaraki M, Lepage G, Mauroy B, Romanin C, Shuba Y, Skryma R and Prevarskaya N. Orai1 contributes to the establishment of an apoptosis-resistant phenotype in prostate cancer cells. Cell. Death Dis. 2010; e75

31. Wasilenko WJ, Cooper J, Palad AJ, Somers KD, Blackmore PF, Rhim JS, Wright GL,Jr and Schellhammer PF. Calcium signaling in prostate cancer cells: evidence for multiple receptors and enhanced sensitivity to bombesin/GRP. Prostate. 1997; 3: 167-173

32. Shiu SY, Pang B, Tam CW and Yao KM. Signal transduction of receptor-mediated antiproliferative action of melatonin on human prostate epithelial cells involves dual activation of Galpha(s) and Galpha(q) proteins. J.Pineal Res. 2010; 3: 301-311

33. Kilch T, Alansary D, Peglow M, Dorr K, Rychkov G, Rieger H, Peinelt $\mathrm{C}$ and Niemeyer BA. Mutations of the $\mathrm{Ca} 2+$-sensing Stromal Interaction Molecule STIM1 Regulate Ca2+ Influx by Altered Oligomerization of STIM1 and by Destabilization of the Ca2+ Channel Orai1. J.Biol. Chem. 2013; 3: 1653-1664

34. Bogeski I, Kummerow C, Al-Ansary D, Schwarz EC, Koehler R, Kozai D, Takahashi N, Peinelt C, Griesemer D, Bozem M, Mori Y, Hoth M and Niemeyer BA. Differential redox regulation of ORAI ion channels: a mechanism to tune cellular calcium signaling. Sci.Signal. 2010; 115: ra24

35. Ji W, Xu P, Li Z, Lu J, Liu L, Zhan Y, Chen Y, Hille B, $\mathrm{Xu} \mathrm{T}$ and Chen L. Functional stoichiometry of the unitary calcium-release-activated calcium channel. Proc.Natl.Acad. Sci.U.S.A. 2008; 36: 13668-13673

36. Penna A, Demuro A, Yeromin AV, Zhang SL, Safrina O, Parker I and Cahalan MD. The CRAC channel consists of a tetramer formed by Stim-induced dimerization of Orai dimers. Nature. 2008; 7218: 116-120

37. Demuro A, Penna A, Safrina O, Yeromin AV, Amcheslavsky A, Cahalan MD and Parker I. Subunit stoichiometry of human Orail and Orai3 channels in closed and open states. Proc.Natl.Acad.Sci.U.S.A. 2011; 43: 17832-17837

38. Madl J, Weghuber J, Fritsch R, Derler I, Fahrner M, Frischauf I, Lackner B, Romanin C and Schutz GJ. Resting state Orail diffuses as homotetramer in the plasma membrane of live mammalian cells. J.Biol.Chem. 2010; 52: 41135-41142

39. Maruyama Y, Ogura T, Mio K, Kato K, Kaneko T, Kiyonaka S, Mori Y and Sato C. Tetrameric Orail is a teardrop-shaped molecule with a long, tapered cytoplasmic domain. J.Biol.Chem. 2009; 20: 13676-13685

40. Thompson JL and Shuttleworth TJ. How Many Orai's Does It Take to Make a CRAC Channel? Sci.Rep. 2013; 1961

41. Hou X, Pedi L, Diver MM and Long SB. Crystal structure of the calcium release-activated calcium channel Orai. Science. 2012; 6112: 1308-1313

42. Soboloff J, Spassova MA, Hewavitharana T, He LP, Xu W, Johnstone LS, Dziadek MA and Gill DL. STIM2 is an inhibitor of STIM1-mediated store-operated Ca2+ Entry. Curr.Biol. 2006; 14: 1465-1470

43. Prakriya $M$ and Lewis RS. Potentiation and inhibition of $\mathrm{Ca}(2+)$ release-activated $\mathrm{Ca}(2+)$ channels by 2-aminoethyldiphenyl borate (2-APB) occurs independently of IP(3) receptors. J.Physiol. 2001; Pt 1: 3-19

44. Peinelt C, Lis A, Beck A, Fleig A and Penner R. 2-Aminoethoxydiphenyl borate directly facilitates and indirectly inhibits STIM1-dependent gating of CRAC channels. J.Physiol. 2008; 13: 3061-3073

45. Lis A, Peinelt C, Beck A, Parvez S, Monteilh-Zoller M, Fleig A and Penner R. CRACM1, CRACM2, and CRACM3 are store-operated $\mathrm{Ca} 2+$ channels with distinct functional properties. Curr.Biol. 2007; 9: 794-800

46. Zhang SL, Kozak JA, Jiang W, Yeromin AV, Chen J, Yu Y, Penna A, Shen W, Chi V and Cahalan MD. Store-dependent and -independent modes regulating $\mathrm{Ca} 2+$ release-activated $\mathrm{Ca} 2+$ channel activity of human Orail and Orai3. J.Biol. Chem. 2008; 25: 17662-17671

47. DeHaven WI, Smyth JT, Boyles RR and Putney JW,Jr. Calcium inhibition and calcium potentiation of Orail, Orai2, and Orai3 calcium release-activated calcium channels. J.Biol.Chem. 2007; 24: 17548-17556

48. Schindl R, Frischauf I, Bergsmann J, Muik M, Derler I, 
Lackner B, Groschner K and Romanin C. Plasticity in Ca2+ selectivity of Orai1/Orai3 heteromeric channel. Proc.Natl. Acad.Sci.U.S.A. 2009; 46: 19623-19628

49. Vanden Abeele F, Shuba Y, Roudbaraki M, Lemonnier L, Vanoverberghe K, Mariot P, Skryma R, Prevarskaya N. Store-operated $\mathrm{Ca} 2+$ channels in prostate cancer epithelial cells: function, regulation, and role in carcinogenesis. Cell Calcium. 2003; 33: 357-73.

50. Prevarskaya N, Skryma R and Shuba Y. Calcium in tumour metastasis: new roles for known actors. Nat.Rev.Cancer. 2011; 8: 609-618

51. Prevarskaya N, Skryma R and Shuba Y. Targeting Ca(2)(+) transport in cancer: close reality or long perspective? Expert Opin.Ther.Targets. 2013; 3: 225-241

52. Monteith GR, McAndrew D, Faddy HM and RobertsThomson SJ. Calcium and cancer: targeting Ca2+ transport. Nat.Rev.Cancer. 2007; 7: 519-530

53. Hoth $\mathrm{M}$ and Penner R. Calcium release-activated calcium current in rat mast cells. J.Physiol. 1993; 359-386

54. Kerschbaum $\mathrm{HH}$ and Cahalan MD. Monovalent permeability, rectification, and ionic block of store-operated calcium channels in Jurkat T lymphocytes. J.Gen.Physiol. 1998; 4: 521-537

55. Bakowski D and Parekh AB. Monovalent cation permeability and $\mathrm{Ca}(2+)$ block of the store-operated $\mathrm{Ca}(2+)$ current I(CRAC )in rat basophilic leukemia cells. Pflugers Arch. 2002; 5-6: 892-902

56. Faouzi M, Hague F, Potier M, Ahidouch A, Sevestre H and Ouadid-Ahidouch H. Down-regulation of Orai3 arrests cellcycle progression and induces apoptosis in breast cancer cells but not in normal breast epithelial cells. J.Cell.Physiol. 2011; 2: 542-551

57. Faouzi M, Kischel P, Hague F, Ahidouch A, Benzerdjeb N, Sevestre H, Penner R and Ouadid-Ahidouch H. ORAI3 silencing alters cell proliferation and cell cycle progression via c-myc pathway in breast cancer cells. Biochim.Biophys. Acta. 2013; 3: 752-760

58. Motiani RK, Zhang X, Harmon KE, Keller RS, Matrougui $\mathrm{K}$, Bennett JA and Trebak M. Orai3 is an estrogen receptor alpha-regulated $\mathrm{Ca} 2+$ channel that promotes tumorigenesis. FASEB J. 2013; 1: 63-75

59. Motiani RK, Abdullaev IF and Trebak M. A novel native store-operated calcium channel encoded by Orai3: selective requirement of Orai3 versus Orai1 in estrogen receptorpositive versus estrogen receptor-negative breast cancer cells. J.Biol.Chem. 2010; 25: 19173-19183

60. Sun YH, Gao X, Tang YJ, Xu CL and Wang LH. Androgens induce increases in intracellular calcium via a $\mathrm{G}$ proteincoupled receptor in LNCaP prostate cancer cells. J.Androl. 2006; 5: 671-678

61. Lieberherr $M$ and Grosse B. Androgens increase intracellular calcium concentration and inositol 1,4,5-trisphosphate and diacylglycerol formation via a pertussis toxin-sensitive G-protein. J.Biol.Chem. 1994; 10:
7217-7223

62. ElBaradie K, Wang Y, Boyan BD and Schwartz Z. Rapid membrane responses to dihydrotestosterone are sex dependent in growth plate chondrocytes. J.Steroid Biochem. Mol.Biol. 2012; 1-2: 15-23

63. Wunderlich F, Benten WP, Lieberherr M, Guo Z, Stamm O, Wrehlke C, Sekeris CE and Mossmann H. Testosterone signaling in T cells and macrophages. Steroids. 2002; 6: 535-538

64. Hoth M and Penner R. Depletion of intracellular calcium stores activates a calcium current in mast cells. Nature. 1992; 6358: 353-356

65. Clinical Trials database search results: http://clinicaltrials.gov/ct2/show/NCT01056029?term=G202\&rank $=2$.

66. Denmeade SR, Mhaka AM, Rosen DM, Brennen WN, Dalrymple S, Dach I, Olesen C, Gurel B, Demarzo AM, Wilding G, Carducci MA, Dionne CA, Moller JV, Nissen $\mathrm{P}$, Christensen SB and Isaacs JT. Engineering a prostatespecific membrane antigen-activated tumor endothelial cell prodrug for cancer therapy. Sci.Transl.Med. 2012; 140: $140 \mathrm{ra} 86$

67. Gmyrek GA, Walburg M, Webb CP, Yu HM, You $\mathrm{X}$, Vaughan ED, Vande Woude GF and Knudsen BS. Normal and malignant prostate epithelial cells differ in their response to hepatocyte growth factor/scatter factor. Am.J.Pathol. 2001; 2: 579-590

68. Grynkiewicz G, Poenie M and Tsien RY. A new generation of $\mathrm{Ca} 2+$ indicators with greatly improved fluorescence properties. J.Biol.Chem. 1985; 6: 3440-3450

69. Mantei A, Rutz S, Janke M, Kirchhoff D, Jung U, Patzel V, Vogel U, Rudel T, Andreou I, Weber M and Scheffold A. siRNA stabilization prolongs gene knockdown in primary T lymphocytes. Eur.J.Immunol. 2008; 9: 2616-2625 